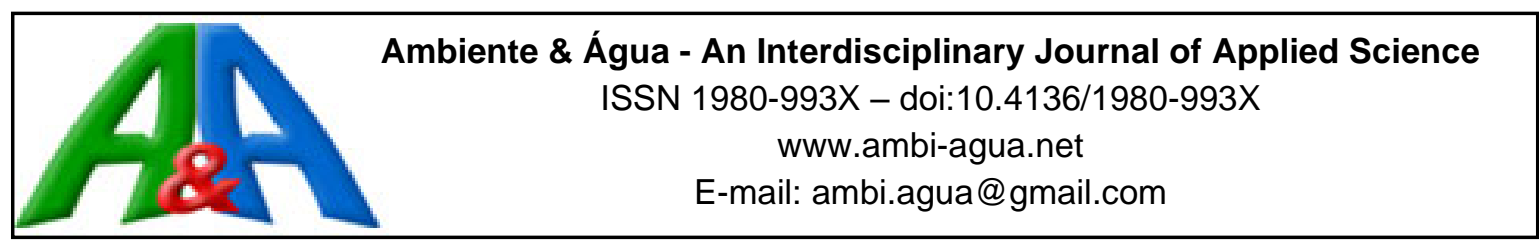

\title{
Development of a Water Quality Index (WQI) for public supply in the Vale do Rio Pardo region, RS, Brazil
}

ARTICLES doi:10.4136/ambi-agua.2711

Received: 18 Feb. 2021; Accepted: 29 Jun. 2021

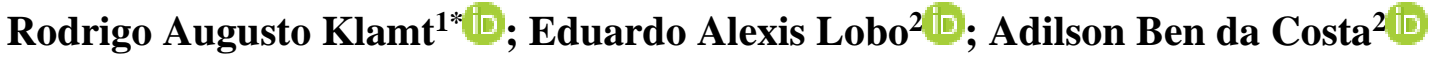 \\ ${ }^{1}$ Pós-graduação em Tecnologia Ambiental. Universidade de Santa Cruz do Sul (UNISC), Avenida \\ Independência, n²293, CEP: 96816-501, Santa Cruz do Sul, RS, Brazil. \\ ${ }^{2}$ Departamento de Ciências da Vida. Universidade de Santa Cruz do Sul (UNISC), Avenida Independência, \\ n²293, CEP: 96816-501, Santa Cruz do Sul, RS, Brazil. E-mail: lobo@unisc.br, adilson@unisc.br \\ *Corresponding author. E-mail: rodrigoklamt@ hotmail.com
}

\begin{abstract}
This research developed a Water Quality Index (WQI) for public supply in the Vale do Rio Pardo Region, RS, Brazil (WQI-VRP), from the database of the 13th Regional Health Coordination, totaling 1175 samples. A filtration process resulted in 285 samples with the variables free residual chlorine, turbidity, apparent color, $\mathrm{pH}$, fluoride, total coliforms and Escherichia coli. For water consumption purposes, the Water Quality Index developed by the Sanitation Company of Goiás, Brazil, was used. A multivariate calibration of the weights of importance of the parameters included in the original index was performed, resulting in the WQI-VRP. Comparing the medians of the two indexes, it was found that there were significant differences $(\mathrm{p}<0.05)$, qualifying the WQI-VRP as more restrictive. The results indicated that $89.8 \%$ of the samples were classified as non-compliant samples by WQI-VRP, while $10.2 \%$ were classified as compliant samples. Of the 285 samples analyzed, 72 samples of chlorine, 12 of total coliform, 5 of E. coli, 2 of color, 200 of fluoride and 26 of pH, were below or above the minimum or maximum values required by Brazilian legislation. The $\mathrm{pH}$ and fluoride correspond to the critical variables of the study region, as they were the parameters that showed the greatest increases in relative weights when comparing the original index with the calibrated one. These results confirm the use of the WQI-VRP as an efficient tool to assess the quality of drinking water in Brazilian subtropical and temperate lotic systems.
\end{abstract}

Keywords: drinking water, environmental monitoring, Vale do Rio Pardo, water quality index.

\section{Desenvolvimento de Índice de Qualidade da Água (IQA) para abastecimento público na região do Vale do Rio Pardo, RS, Brasil}

\section{RESUMO}

Esta pesquisa teve como objetivo desenvolver um índice de qualidade da água para abastecimento público na Região do Vale do Rio Pardo, RS, Brasil, IQA-VRP, utilizando o banco de dados da $13^{a}$ Coordenadoria Regional de Saúde, totalizando 1175 amostras. Um processo de filtragem resultou em 285 amostras com as variáveis Cloro residual livre, turbidez, cor aparente, $\mathrm{pH}$, fluoretos, coliformes totais e Escherichia coli. Para fins de potabilidade, foi utilizado o Índice de Qualidade da Água desenvolvido pela Companhia de Saneamento de Goiás, Brasil. Realizamos uma calibração multivariada dos pesos de importância dos parâmetros incluídos no índice original, resultando no IQA-VRP. Comparando as medianas dos dois índices, verificou-se que houve diferenças significativas $(p<0,05)$, 
qualificando o IQA-VRP como mais restritivo. Os resultados indicaram que 89,8\% das amostras foram classificadas como produtos não conformes pelo IQA-VRP, enquanto 10,2\% foram classificadas como produtos conformes, e das 285 amostras analisadas, 72 amostras de cloro, 12 de coliformes totais, 5 de E. coli, 2 de cor, 200 de flúor e 26 de $\mathrm{pH}$, estavam abaixo ou acima dos valores mínimos ou máximos exigidos pela legislação brasileira. $\mathrm{O}$ pH e o flúor correspondem às variáveis críticas da região de estudo, pois foram os parâmetros que apresentaram os maiores aumentos nos pesos relativos comparando o índice original com o calibrado. Esses resultados confirmam o uso do IQA-VRP como ferramenta eficiente para avaliar a qualidade da água potável em sistemas lóticos subtropicais e temperados brasileiros.

Palavras-chave: água potável, índice de qualidade de água, monitoramento ambiental, Vale do Rio Pardo.

\section{INTRODUCTION}

Water is an essential resource that guarantees the health to the population, being considered a priority for environmental health surveillance actions in Brazil. However, unsustainable development patterns have favored environmental degradation, thanks to significant changes in the natural environment and the destruction of diverse ecosystems, including aquatic water bodies, which lead to changes in disease distribution patterns and health conditions in different population groups. Water is a basic requirement for the sustainability of all living beings on this planet. Several factors, such as population growth, urbanization, economic growth and changes in climate patterns, have contributed to an increase in water scarcity worldwide and, as a result, water resource management has become a global problem (Bawoke et al., 2020). In addition, its pollution by human activities, waste and exploitation can make drinking water increasingly scarce, threatening the quantity and quality of water, and consequently, the public supply and associated food production (Usepa, 2005; Subba et al., 2017; Varade et al., 2018; Duraisamy et al., 2019; Aravinthasamy et al., 2021; Gaikwad et al., 2020; Wagh et al., 2020). Thus, raw water and its quality assessment are essential for preserving the quality of water resources, sustainable development and improving the quality of drinking water, avoiding serious health problems (Kadam, 2021).

The debate on issues related to water quality and the role of the Ministry of Health in consumption parameters is not recent. Since 1977, the Ministry has had the power to develop norms and standards for drinking water for human consumption. Thus, monitoring the quality of water for human consumption was the first type of environmental health surveillance in Brazil (Brasil, 2005). The evaluation of water quality in Brazil is carried out through Resolution No. 357 of the National Environment Council (CONAMA, 2005). This classifies freshwater into five different classes according to the uses for which it is intended, from a special class, of better quality, destined to supply for human consumption with disinfection and the preservation of the natural balance of aquatic communities, up to Class 4 , of worse quality, which is intended only for navigation and landscape harmony.

Among the physical and chemical methods proposed to assess water quality, the Water Quality Index (WQI), originally developed by the National Sanitation Foundation of the United States (Brown et al., 1970), is one of the most used. To apply WQI in lotic systems in Southern Brazil, Moretto et al. (2012) calibrated the weights of the importance of the parameters used in the formulation of the WQI for the Pardo River Basin, applying multivariate analysis techniques. They found a significant agreement between the new calibrated weights and CONAMA Resolution 357/2005, being suitable for use in environmental monitoring programs (e.g., Wiesel et al., 2018; Klamt et al., 2019).

For the supply of water for human consumption, the Environmental Company of the State of São Paulo, Brazil (CETESB) developed the WQI for public supply purposes, which 
represented an improvement over the original WQI, as it incorporated variables related to health risks for consumers and the acceptance of water for human consumption (CETESB, 2002). In Goiás, Brazil, the Sanitation Company (SANEAGO) developed a WQI to evaluate treated drinking water known as WQI-SANEAGO (SANEAGO, 2012). The methodology considers the results obtained through the analysis of nine parameters (free residual chlorine, turbidity, color, $\mathrm{pH}$, total iron, residual aluminum, total coliforms and Escherichia coli), adopting as acceptance criteria the specifications of Annex XX of the Consolidation Ordinance $\mathrm{n}^{\circ} 5$ of 2017 (Brasil, 2017). This ordinance provides for the control and inspection of the quality of water for human consumption and its drinking water standards. In Brazil, WQI's are used in the evaluation of drinking water for human consumption and also in the adaptations made to monitor the water produced and distributed (e.g., Facincani et al., 2001; Pierin et al., 2005; Marques et al., 2007; SANEAGO, 2012; Fernardes et al., 2015; Silva et al., 2017).

The proposal for a WQI to assess the quality of the water we consume is a practical and objective way of informing the general population, technicians and operators of treatment plants about the characteristics of the water supply. In this way, it will facilitate communication in the professional area and also provide the public with greater clarification about water quality, as set out in the specifications contained in Annex XX of Consolidation Ordinance 05 of 2017 (Brasil, 2017). This ordinance establishes definitions and procedures on the control of water quality in supply systems and institutes mechanisms and instruments for the dissemination of information to consumers on the quality of water for human consumption. Therefore, public awareness of the need to preserve surface waters can be promoted by predicting future problems in catchment areas. In this context, this study aimed to develop a WQI for public supply in the Vale do Rio Pardo Region, State of Rio Grande do Sul, Brazil.

\section{MATERIAL AND METHODS}

\subsection{Study area}

The total population of the Vale do Rio Pardo Region was 438,800 inhabitants (2019), with an area of 13,171.7 km² (2015), comprising 23 municipalities as shown in Figure 1 (FEE, 2019).

\subsection{Sampling}

We used the database of the 13th Regional Health Coordination, located in the Municipality of Santa Cruz do Sul, Brazil, which covers the municipalities of Vale do Rio Pardo Region (Figure 1). This database corresponds to the years 2016 and 2017, for the municipalities

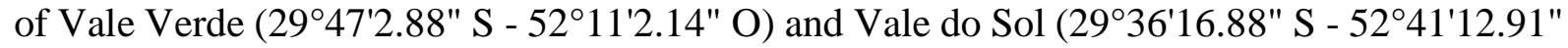
O) (WGS 84), totaling 1175 samples of water for human consumption. A filtration process was carried out to verify that all variables were measured in all samples, resulting in 285 samples that included seven variables, namely, free residual chlorine, turbidity, apparent color, $\mathrm{pH}$, fluoride, total coliforms and Escherichia coli. The techniques used in collecting samples and determining variables are described in APHA et al. (2005).

From the set of measured variables, we selected the WQI developed by the Sanitation Company of Goiás for drinking purposes (SANEAGO, 2012), since almost all the variables are included in our database, with the exception of aluminum and iron. Therefore, the importance weights of these variables were redistributed in the other parameters for calculating the index (Table 1). 


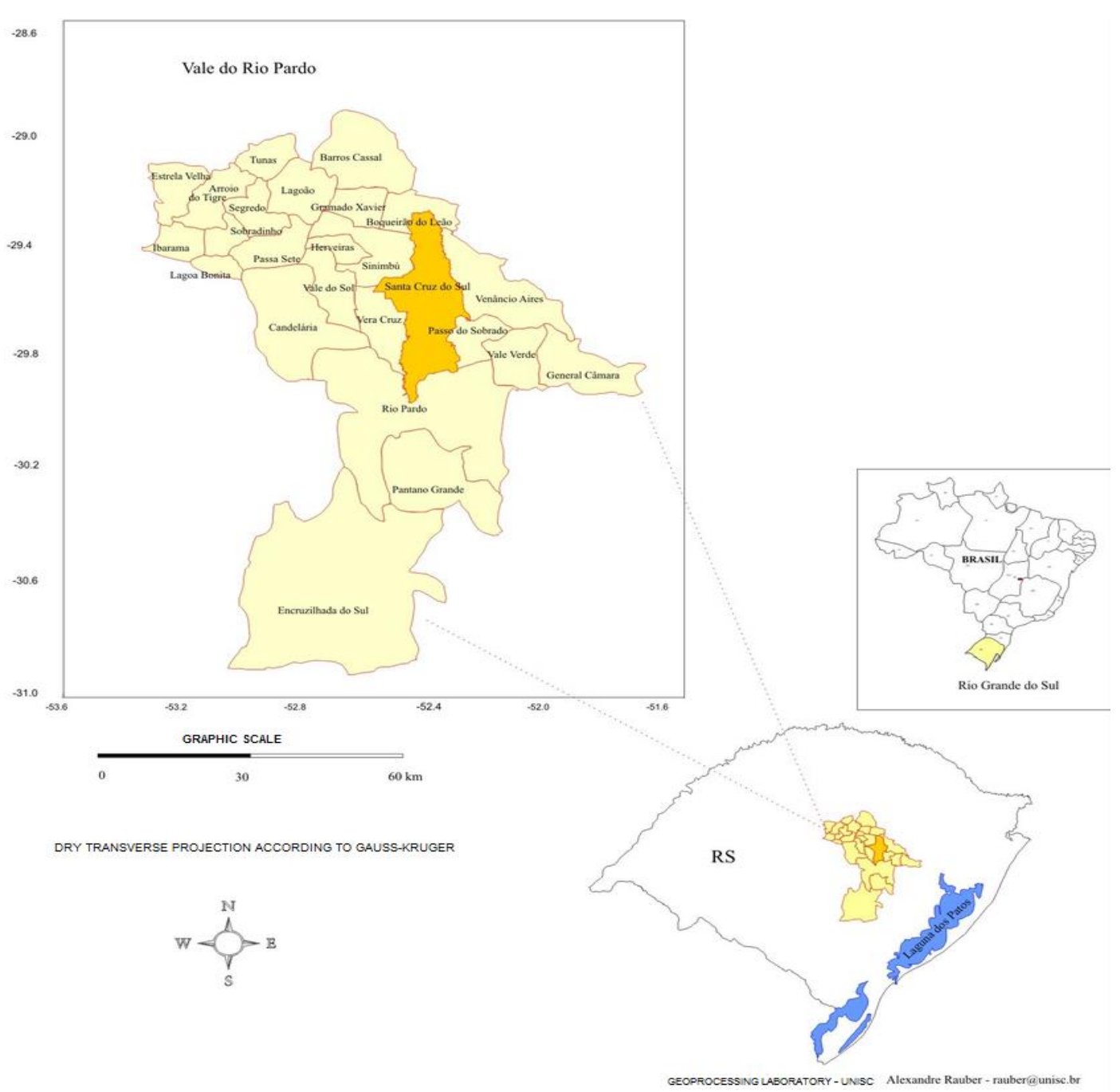

Figure 1. Location map of the 23 municipalities belonging to the 13th Regional Health Coordination, located in the Municipality of Santa Cruz do Sul, Vale do Rio Pardo, Brazil.

Table 1. Redistribution of weights from WQI-SANEAGO (2012). E. coli (Escherichia coli - NMP 100 $\left.\mathrm{mL}^{-1}\right)$, C. Total, (Total coliforms - NMP $\left.100 \mathrm{~mL}^{-1}\right)$, Fluoride $\left(\mathrm{mg} \mathrm{L}^{-1}\right)$, color $(\mathrm{uH}), \mathrm{pH}(\mathrm{pH})$, Free RC (free residual chlorine $\left.-\mathrm{mg} \mathrm{L}^{-1}\right)$, turbidity $(\mathrm{UNT})$, aluminum $\left(\mathrm{mg} \mathrm{L}^{-1}\right)$ and iron $\left(\mathrm{mg} \mathrm{L}^{-1}\right)$. Adapted from SANEAGO (2012).

\begin{tabular}{cccccc}
\hline Variables & $\begin{array}{c}\text { Weights } \\
\text { WQI- } \\
\text { SANEAGO } \\
\mathbf{( 2 0 1 2 )}\end{array}$ & $\begin{array}{c}\text { Measured } \\
\text { variables }\end{array}$ & $\begin{array}{c}\text { Contribution of } \\
\text { variables (0.88) }\end{array}$ & $\begin{array}{c}\text { Weight to be } \\
\text { distributed }\end{array}$ & $\begin{array}{c}\text { Redistributed } \\
\text { weights } \\
\text { WQI-SANEAGO } \\
\text { (2012) }\end{array}$ \\
\hline E. coli & 0.16 & 0.16 & 18.2 & - & 0.18 \\
C. Total & 0.16 & 0.16 & 18.2 & - & 0.18 \\
Fluoride & 0.09 & 0.09 & 10.2 & - & 0.10 \\
Color & 0.12 & 0.12 & 13.6 & - & 0.14 \\
pH & 0.07 & 0.05 & 8.0 & - & 0.18 \\
Free RC & 0.16 & 0.16 & 18.2 & - & 0.14 \\
Turbidity & 0.12 & 0.12 & 13.6 & 0.06 & - \\
Aluminum & 0.06 & - & - & 0.06 & - \\
ions & 0.06 & - & - & 0.12 & 1 \\
Total Iron & 1 & 0.88 & $100 \%$ & & \\
ions & & & & & \\
\hline Total & & & & & \\
\hline
\end{tabular}


The WQI-VRP is calculated similarly to the WQI of the National Sanitation Foundation (Brown et al., 1970), with the weighted product of the water quality corresponding to each evaluated parameter, using Equation 1.

$$
W Q I \_V R P=\prod_{i=1}^{n} q_{i}^{w_{i}}
$$

Where:

П: product symbol;

qi: relative quality of the i-th parameter;

wi: relative weight of the i-th parameter (Table 1);

i: parameter order number (1 to 7).

The calculation of the WQI-VRP requires a standardization step, where each parameter is transformed into a scale from $0-100 \%$, where $100 \%$ represents the highest quality.

\subsection{Data analysis}

In the data analysis, descriptive statistics (median and percentiles) were used and the statistical differences between the indices were established using the Mann-Whitney nonparametric test, following the recommendations of Hammer et al. (2001). Significance level $\alpha$ $=5 \%$ was used. The calibration of the WQI-VRP for the selected database of the 13th Regional Health Coordination, in 2016 and 2017, was carried out through the Principal Component Analysis (PCA), following the recommendations of Gotelli and Ellison (2013) and Jackson (1993). All calculations were performed using the PAST statistical program (Hammer et al., 2001).

\section{RESULTS AND DISCUSSION}

From the 285 samples included in the database of the 13th Regional Health Coordination, the averages ( \pm standard deviation) of the seven variables that were measured were calculated (Table 2). As can be seen in Table 2, when we evaluated the average, most variables showed values according to the range allowed by Brazilian legislation for drinking water, according to the specifications contained in Annex XX of Consolidation Ordinance 05 of 2017 (BRASIL, 2017), with the exception of the fluoride variable, which on average $\left(0.4 \pm 0.5 \mathrm{mg} \mathrm{L}^{-1}\right)$ was below the minimum value $\left(0.6 \mathrm{mg} \mathrm{L}^{-1}\right)$. However, due to the high coefficients of variation $(\mathrm{CV})$ obtained for all variables, with the exception of $\mathrm{pH}(\mathrm{CV}=12.5 \%)$, which ranged from $92.1 \%$ for free residual chlorine, up to $700 \%$ for $E$. coli, there is a series of samples in which the variables were below the minimum values or above the maximum values required by legislation (Brasil, 2017), as will be discussed later. For example, in the case of fluoride, which presented a $\mathrm{CV}=125 \%, 200$ samples $(70.2 \%)$ were above the maximum required values, being characterized as non-compliant samples.

Table 3 presents the eigenvalues that correspond to the variances of the main components of the Principal Component Analysis (PCA). Considering that the physical, chemical and microbiological variables were measured using different units, the normalized variancecovariance matrix correlation was used (Hammer et al., 2001). The PCA revealed $49.0 \%$ of the total variance in the first two components. According to Ter Braak and Prentice (1988), this average explainability is expected in the analysis of the ordering of abiotic data and confirms the complexity of environmental factors. Thus, the coefficients of the variables (eigenvectors) to be extracted must belong to one of these two main components, since they were defined as 
significant components using the Broken Stick model of the eigenvalue graph (Jackson, 1993).

Table 2. Average values ( \pm standard deviation) and the coefficients of variation of the seven variables that were measured in the 285 samples from the database of the 13th Regional Health Coordination. C. Total (Total coliforms), E. coli (Escherichia coli), Free RC (Free residual chlorine).

\begin{tabular}{cccc}
\hline Variable & $\begin{array}{c}\text { Limit values } \\
(\text { Brasil, 2017) }\end{array}$ & $\begin{array}{c}\text { Average } \\
( \pm \text { standard deviation) }\end{array}$ & Coefficient of Variation \\
\hline C. Total (NMP 100 $\left.\mathrm{mL}^{-1}\right)$ & $\begin{array}{c}0=\text { absent } \\
1=\text { present }\end{array}$ & $0.05 \pm 0.22$ & $440.0 \%$ \\
\hline E. coli (NMP 100 $\left.\mathrm{mL}^{-1}\right)$ & $\begin{array}{c}0=\text { absent } \\
1=\text { present }\end{array}$ & $0.02 \pm 0.14$ & $700.0 \%$ \\
\hline Free RC (mg L $\left.{ }^{-1}\right)$ & $<0.2-\geq 2.0$ & $0.5 \pm 0.4$ & $80.0 \%$ \\
\hline Color $(\mathrm{uH})$ & $<15$ & $3.6 \pm 5.0$ & $138.9 \%$ \\
\hline $\mathrm{pH}$ & $6.0-9.5$ & $7.2 \pm 0.9$ & $12.5 \%$ \\
\hline Turbidity $(\mathrm{UNT})$ & $\leq 5$ & $0.3 \pm 0.6$ & $200.0 \%$ \\
\hline Fluoride $\left(\mathrm{mg} \mathrm{L}{ }^{-1}\right)$ & $0.60-0.86$ & $0.4 \pm 0.5$ & $125.0 \%$ \\
\hline
\end{tabular}

Table 3. Eigenvalues (in bold, the main significant components stand out) and percentages of the accumulated variance of the abiotic data measured in 285 samples from the database of the 13th Regional Health Coordination, in the years 2016 and 2017.

\begin{tabular}{rccc}
\hline Main Component & Eigenvalues & Total variance & Accumulated variance \\
\hline Component 1 & $\mathbf{1 . 8 2 8 4 1}$ & $\mathbf{2 6 . 4 \%}$ & $\mathbf{2 6 . 4 \%}$ \\
Component 2 & $\mathbf{1 . 5 7 7 4 5}$ & $\mathbf{2 2 . 6 \%}$ & $\mathbf{4 9 . 0 \%}$ \\
Component 3 & 1.40278 & $19.6 \%$ & $68.6 \%$ \\
Component 4 & 0.96115 & $13.7 \%$ & $82.3 \%$ \\
Component 5 & 0.56270 & $8.0 \%$ & $90.3 \%$ \\
Component 6 & 0.35530 & $5.2 \%$ & $95.5 \%$ \\
Component 7 & 0.31220 & $4.5 \%$ & $100 \%$ \\
\hline
\end{tabular}

Figure 2 shows the bivariate graph of the main components PC1 and PC2, according to the seven abiotic variables used. Table 4 shows the eigenvectors used to interpret the main components. The most important variables are those of greater weight, negative or positive, and the sign of the weights indicates whether the correlation is positive or negative. 


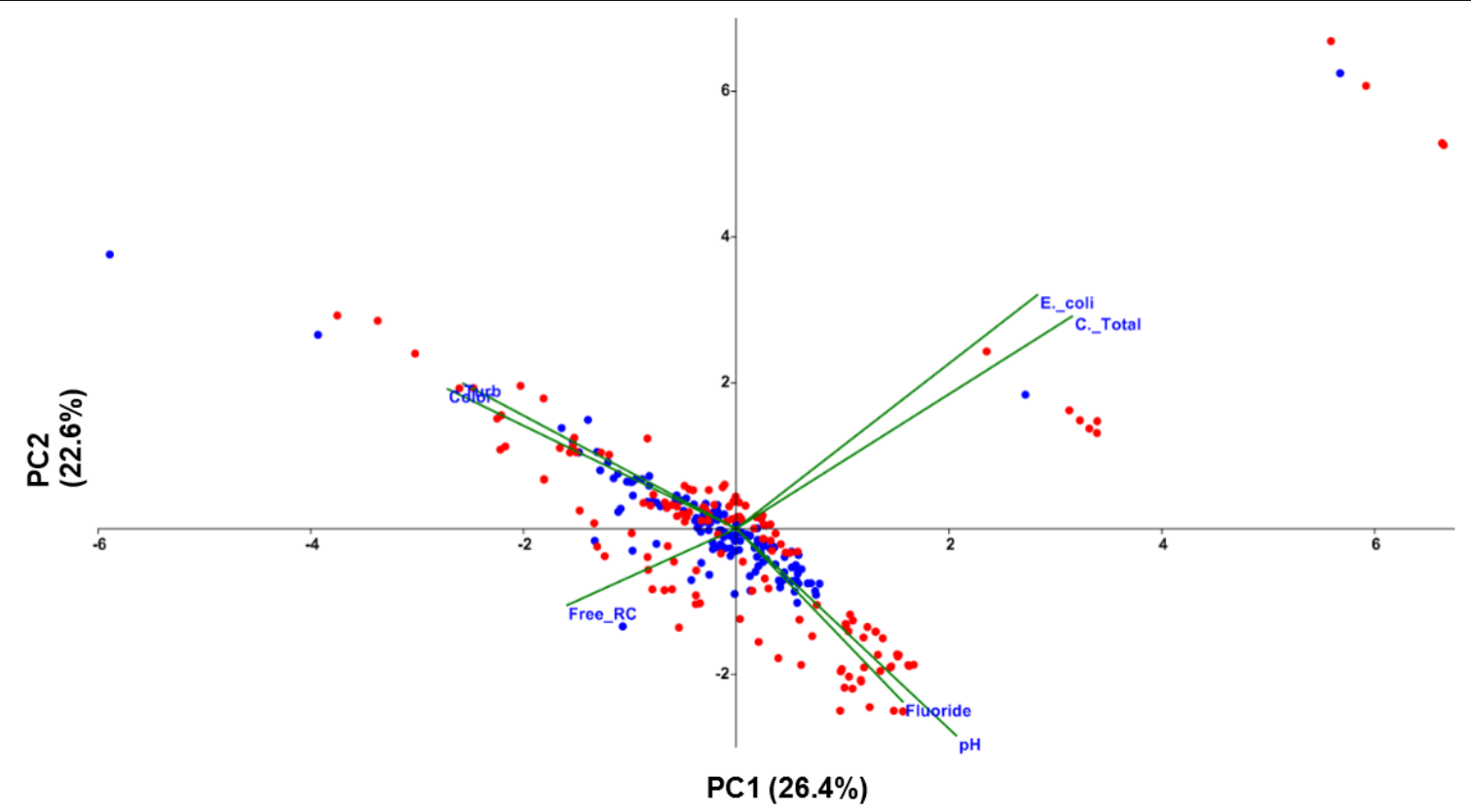

Figure 2. Bivariate graph of the main components $\mathrm{PC} 1$ and $\mathrm{PC} 2$, of the abiotic data measured in 285 samples from the database of the 13th Regional Health Coordination, in the years 2016 and 2017, in the municipalities of Vale Verde (blue color) and Vale do Sol (red color). E. coli (Escherichia coli - NMP $100 \mathrm{~mL}^{-1}$ ), C. Total (Total coliforms - NMP $\left.100 \mathrm{~mL}^{-1}\right)$, Fluoride $\left(\mathrm{mg} \mathrm{L}^{-}\right.$ $\left.{ }^{1}\right)$, Color (uH), $\mathrm{pH}(\mathrm{pH})$, Free RC (mg L $\left.{ }^{-1}\right)$, Turb. (Turbidity - UNT).

Table 4. Eigenvectors (in bold the extracted coefficients are highlighted) of the abiotic data measured in 285 samples from the database of the 13th Regional Health Coordination, in the years 2016 and 2017. C. Total (Total coliforms), E. coli (Escherichia coli), Free RC (Free residual chlorine).

\begin{tabular}{ccc}
\hline Variable & Main Component (PC1) & Main Component (PC2) \\
\hline C. Total (NMP 100 $\left.\mathrm{mL}^{-1}\right)$ & $\mathbf{0 . 7 0 8 5}$ & 0.5236 \\
E. coli (NMP 100 $\left.\mathrm{mL}^{-1}\right)$ & $\mathbf{0 . 6 4 4 4}$ & 0.5817 \\
Free RC $\left(\mathrm{mg} \mathrm{L}^{-1}\right)$ & $\mathbf{- 0 . 2 9 9 9}$ & -0.2424 \\
Color (uH) & $\mathbf{- 0 . 5 5 5 9}$ & 0.4168 \\
$\mathrm{pH}$ & 0.3877 & $\mathbf{- 0 . 5 6 4 8}$ \\
Turbidity $(\mathrm{UNT})$ & $\mathbf{- 0 . 5 3 0 2}$ & 0.4446 \\
Fluoride $\left(\mathrm{mg} \mathrm{L}^{-1}\right)$ & 0.2843 & $\mathbf{- 0 . 4 6 4 6}$ \\
\hline
\end{tabular}

For the calibration of the WQI-VRP, the eigenvector coefficients used were those significant for each of the environmental variables selected from both PC1 and PC2, depending on the importance of their weight (higher coefficient). As the total sum of the eigenvectors coefficients (weights) is equal to 3.7683 (Table 4), it was necessary to carry out a mathematical transformation of the coefficients, since the sum of the weights of the coefficients in the formula for calculating the WQI must be equal to 1 . Table 5 shows the mathematical transformation, dividing each of the values of the coefficients (weights) by the total sum of the coefficients, thus obtaining the new weights for the selected environmental variables. 
Table 5. Calibration of WQI-VRP weights in 285 samples from the database of the 13th Regional Health Coordination, in the years 2016 and 2017. C. Total (Total Coliforms - NMP $100 \mathrm{~mL}^{-1}$ ), E. coli (Escherichia coli - NMP $100 \mathrm{~mL}^{-1}$ ), Free RC (Free residual chlorine - $\mathrm{mg} \mathrm{L}^{-1}$ ).

\begin{tabular}{cccc}
\hline Variables & Eigenvectors & Mathematical transformation & $\begin{array}{c}\text { WQI-VRP } \\
\text { Calibrated weight (2021) }\end{array}$ \\
\hline C. Total (NMP 100 $\left.\mathrm{mL}^{-1}\right)$ & 0.7085 & $0.7085 / 3.7683$ & 0.19 \\
E. coli (NMP 100 mL-1) & 0.6444 & $0.6444 / 3.7683$ & 0.17 \\
Color (uH) & 0.5559 & $0.5559 / 3.7683$ & 0.15 \\
Turbidity (UNT) & 0.5302 & $0.5302 / 3.7683$ & 0.14 \\
Free RC (mg L $\left.{ }^{-1}\right)$ & 0.2999 & $0.2999 / 3.7683$ & 0.08 \\
pH & 0.5648 & $0.5649 / 3.7683$ & 0.15 \\
Fluoride (mg L $\left.{ }^{-1}\right)$ & 0.4646 & $0.4646 / 3.7683$ & 0.12 \\
\hline Total sum & 3.7683 & - & 1 \\
\hline
\end{tabular}

Table 6 presents a comparison of the weights of the variables included in the WQISANEAGO (2012), which incorporated a redistribution of the weights of the aluminum and iron variables, since they are not included in the selected database (Table 1), with the new weights calibrated for WQI-VRP, using eigenvectors of the significant coefficients for each of the environmental variables selected from the PCA (PC1 and PC2), in 285 samples from the database of the 13th Regional Health Coordination.

Table 6. Comparative analysis of the variables weights of the WQI-SANEAGO (2012) with the weights of the WQI-VRP, in 285 samples from the database of the 13th Regional Health Coordination, in the years 2016 and 2017. C. Total (Total coliforms - NMP $100 \mathrm{~mL}^{-1}$ ), E. coli (Escherichia coli - NMP $100 \mathrm{~mL}^{-1}$ ), Free RC (Free residual chlorine - $\mathrm{mg} \mathrm{L}^{-1}$ ).

\begin{tabular}{|c|c|c|}
\hline Variables & $\begin{array}{l}\text { WQI-SANEAGO (2012) } \\
\text { Redistributed Weights }\end{array}$ & $\begin{array}{c}\text { WQI-VRP } \\
\text { Calibrated Weights }\end{array}$ \\
\hline C. Total (NMP $100 \mathrm{~mL}^{-1}$ ) & 0.18 & 0.19 \\
\hline E. coli (NMP $\left.100 \mathrm{~mL}^{-1}\right)$ & 0.18 & 0.17 \\
\hline Free $\mathrm{RC}\left(\mathrm{mg} \mathrm{L}^{-1}\right)$ & 0.18 & 0.08 \\
\hline Color (uH) & 0.14 & 0.15 \\
\hline Turbidity (UNT) & 0.14 & 0.14 \\
\hline Fluoride $\left(\mathrm{mg} \mathrm{L}^{-1}\right)$ & 0.10 & 0.12 \\
\hline $\mathrm{pH}$ & 0.08 & 0.15 \\
\hline Total & 1 & 1 \\
\hline
\end{tabular}

From the calibration of the weights of WQI-VRP, it is observed that the variables that presented the greatest increases in relative weights in relation to the WQI-SANEAGO (2012) were $\mathrm{pH}$ and fluoride, which increased $87.5 \%$ and $20.0 \%$, respectively. The $\mathrm{pH}$ went from 0.08 to 0.15 , and fluoride went from 0.10 to 0.12 (Table 6). Free residual chlorine, on the other hand, showed the greatest decrease in relative weight in relation to the WQI-SANEAGO (2012), $55.5 \%$, decreasing from 0.18 to 0.08 . These results indicate that the $\mathrm{pH}$ and fluoride of the water correspond to the critical variables in the region of the study. 
The scores attributed to each of the parameters used to determine the WQI-VRP are related to compliance with the values and specifications contained in Annex XX of Consolidation Ordinance $n^{\circ} 5$ of 2017 (Brasil, 2017), as shown in Table 7, which shows the limit values allowed to consider drinking water, as well as the scores attributed to this condition. Of the 285 samples collected, the scores corresponding to each measured parameter were assigned based on the classification shown in Table 7. Then, using the WQI-VRP (2021) with the calibrated weights (Table 6), the WQI values were calculated for each sample using Equation 1.

Table 7. Limit values and scores attributed to the variables used in the calculation of the WQI-VRP. E. coli (Escherichia coli), C. Total (Total coliforms), Free RC (Free residual chlorine).

\begin{tabular}{|c|c|c|}
\hline Parameter & Value & Score \\
\hline \multirow{2}{*}{ E. coli (NMP $\left.100 \mathrm{~mL}^{-1}\right)$} & Absent $<1.1$ & 100 \\
\hline & Present $\geq 1.1$ & 1 \\
\hline \multirow{2}{*}{ C. Total (NMP $\left.100 \mathrm{~mL}^{-1}\right)$} & Absent $<1.1$ & 100 \\
\hline & Present $\geq .1 .1$ & 1 \\
\hline \multirow{5}{*}{ Fluoride $\left(\mathrm{mg} \mathrm{L}^{-1}\right)$} & 0.55 & 1 \\
\hline & $0.55-0.59$ & 5 \\
\hline & $0.60-0.80$ & 100 \\
\hline & $0.81-0.86$ & 5 \\
\hline & $>0.86$ & 1 \\
\hline \multirow{2}{*}{ Color (uH) } & $<15.00$ & 100 \\
\hline & $\geq 15.01$ & 1 \\
\hline \multirow{3}{*}{$\mathrm{pH}$} & $\leq 5.99$ & 1 \\
\hline & $6.0-9.5$ & 100 \\
\hline & $\geq 9.51$ & 1 \\
\hline \multirow{3}{*}{ Free RC $\left(\mathrm{mg} \mathrm{L}^{-1}\right)$} & $<0.20$ & 1 \\
\hline & $0.20-2.00$ & 100 \\
\hline & $\geq 2.01$ & 1 \\
\hline \multirow{3}{*}{ Turbidity (UNT) } & $\leq 5.0$ & 100 \\
\hline & $5.01-7.5$ & 50 \\
\hline & $\geq 7.51$ & 1 \\
\hline
\end{tabular}

The results indicated that the median for WQI-SANEAGO (2012) was equal to 63.1, while for WQI-VRP the median was equal to 52.5 (Figure 3), with a significant difference ( $\mathrm{p}<0.05$ ). This difference implies that WQI-VRP is more restrictive than WQI-SANEAGO (2012), therefore characterizing the region's water quality more efficiently and may even better reflect conditions unfit for human consumption than higher WQI's, such as is the case of WQISANEAGO (2012). For these reasons, the WQI-VRP was selected to be applied in the region. 


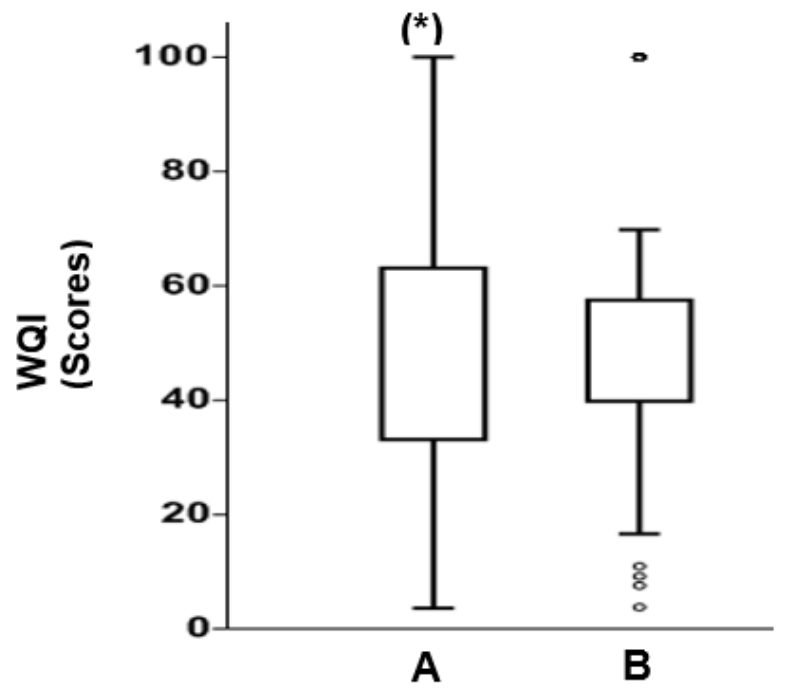

Figure 3. Box Plot for the Water Quality Index (WQI, $\mathrm{n}=285$ ), comparing the WQI-SANEAGO (2012) with a median of 63.1 (A), with the WQIVRP with a median of 52.5 (B). (*): Significant difference $(\mathrm{p}<0.05)$.

The value obtained by calculating the WQI-VRP is categorized by ranges (SANEAGO, 2012), from 1 to 63 is considered "non-compliant sample", and from 64 to 100 as "compliant sample" (Figure 4). Thus, the results indicated that $89.8 \%$ of the samples were classified as non-compliant samples by WQI-VRP, while $10.2 \%$ of them were classified as compliant samples (Figure 4). This condition could be explained considering that of the 285 samples analyzed, 72 of free residual chlorine, 12 of total coliform, five of E. coli, two of color, 200 of fluoride and 26 of $\mathrm{pH}$ were below the minimum values or above the maximum values required by law, characterizing the 256 non-compliant samples. These results coincide with the interpretation made in the Principal Component Analysis - PCA (Fig. 2 and Table 4), which highlighted Axis 2 as significant with the highest correlation coefficients for $\mathrm{pH}(-0.5648)$ and fluoride (-0.4646). Likewise, $\mathrm{pH}$ and fluoride were the parameters that showed the greatest increases in relative weights comparing WQI-SANEAGO (2012) with WQI-VRP, 87.5\% and $20.0 \%$, respectively (Table 6). This analysis shows that these parameters correspond to the critical variables of the study region.

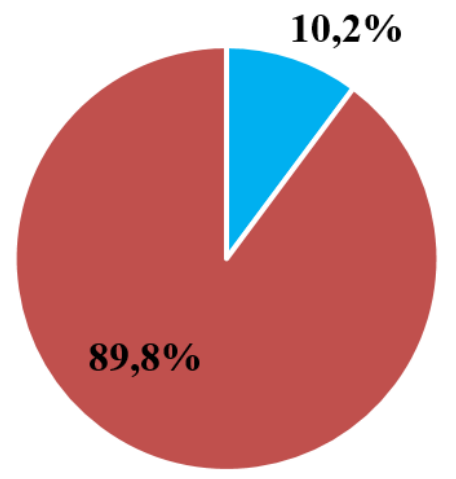

\section{- Compliant sample $\quad$ Non-compliant sample}

Figure 4. Water classification by WQI-VRP, referring to 285 samples between the years 2016 and 2017 . 
To standardize the categorization, we adopted the scoring range following the WQI classification developed by the Canadian Council of the Ministry of the Environment (Saffran et al., 2001), and recommended by the United Nations to assess drinking water using WQI on a global level (Rickwood and Carr, 2009). The results in Figure 5 indicate that in the "excellent" category, with scores between 95 and 100, where water quality is present in conditions very close to the desirable levels or in perfect condition, $6.3 \%$ of the samples were included in this category. In the "good" category, with scores between 80 and 94 , where water quality is protected, and circumstances rarely differ from desirable levels; no sample was placed in this category.

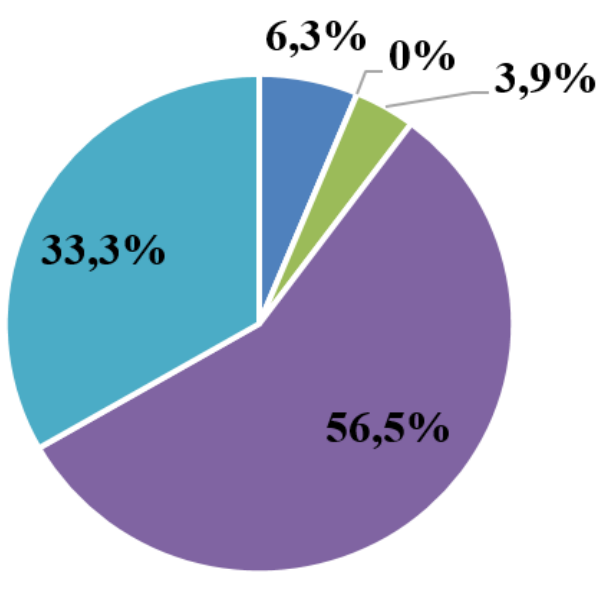

\section{- Excellent $\backsim$ Good $\backsim$ Regular $\backsim$ Marginal $\backsim$ Poor}

Figure 5. Water classification by WQI-VRP, following the standards proposed by the Canadian Council of the Ministry of Environment (Saffran et al., 2001), and recommended by the UN (Rickwood and Carr, 2009).

In the "regular" category, with scores of $65-79$, where water quality is generally protected, but occasionally threatened, and may be distanced from the desired levels, $3.9 \%$ of the samples were included in this category. In the "marginal" category, with scores between 45 and 64, where water quality is frequently threatened, depending on the circumstances and the distance from desirable levels, $56.5 \%$ of the samples were included in this category. Finally, in the "poor" category, with scores of $0-44$, where water quality is usually threatened, generally distancing from the desired levels, $33.3 \%$ of the samples were included in this category. It is important to highlight that the categories "marginal" and "poor" in the classification (Richwood and Carr, 2009) are equivalent to the classification of the samples as "Non-compliant sample" using the WQI-VRP, where in both classifications $89.8 \%$ of the samples were included.

In general, the results indicated that the fluoride and $\mathrm{pH}$ parameters correspond to the critical variables of the study region, and the excess of fluoride ions is harmful to public health, since according to Consolidation Ordinance $\mathrm{N}^{\mathrm{o}}$. 05 of 2017 of Ministry of Health (Brasil, 2017), the ingestion of water with fluoride concentrations above $1.5 \mathrm{mg} \mathrm{L}^{-1}$ can cause dental fluorosis in children, which results from defective mineralization of the tooth enamel matrix, directly associated to the amount of water ingested with high fluoride concentrations (Baumann et al., 2018). Among the quality parameters monitored in the public water supply, fluoride has attracted the attention of surveillance agencies due to the frequency with which values are identified that do not meet the potability standards (Pappis et al., 2020). The fluoride concentration in adequate amounts acts to prevent dental caries (Costa et al., 2018). 
In the chemical treatment of water, coagulation alters the balance of the carbonate system, tending to decrease the $\mathrm{pH}$ when the coagulant is diluted, due to hydrolysis that releases hydrogen ions and reduces alkalinity. Likewise, chlorine disinfection reduces alkalinity and $\mathrm{pH}$, due to the acid-base properties of chlorine, which, when hydrolyzed, forms hypochlorous acid, which dissociates into hydrogen ions (WHO, 2011). These phenomena make it necessary to readjust the chemical balance of water at the end of the treatment, to guarantee its stability in the water distribution system and its potability (Edzwald, 2010). The $\mathrm{pH}$ range for public water supplies is established by legislation between 6.5 and 9.5. This parameter aims to minimize the problems of scaling and corrosion of the distribution networks (Brasil, 2017).

Another parameter that drew attention was the free residual chlorine, which presented 72 non-compliant samples, highlighting that during transport the water undergoes a process of degradation of its quality, due to the detention time and the state of conservation and maintenance of the network, representing a risk to the health and safety of the supplied population (Nascimento et al., 2016).

\section{CONCLUSION}

A multivariate calibration of the weights of importance of the parameters included in the original Water Quality Index (WQI) for drinking water was carried out, developed by the Sanitation Company of Goiás, Brazil, the WQI-SANEAGO (2012), resulting in the WQI-VRP, a WQI for public supply in the Vale do Rio Pardo Region, RS, Brazil. Comparing the medians of the two indexes, it was found that there were significant differences $(\mathrm{p}<0.05)$, qualifying the WQI-VRP as more restrictive, characterizing the water quality of the region more efficiently and may even better reflect conditions unfit for human consumption than higher WQI's, such as is the case of WQI-SANEAGO (2012).

Regarding water quality, the results indicated that $89.8 \%$ of the samples were classified as non-compliant samples using the WQI-VRP, while $10.2 \%$ of them were classified as compliant samples. This condition is explained considering that, of the 285 samples analyzed, 72 of free residual chlorine, 12 of total coliform, five of E. coli, two of color, 200 of fluoride and 26 of $\mathrm{pH}$ were below the minimum values or above the maximum values required by Brazilian law. These results coincide with the interpretation made in the Principal Component Analysis (PCA), which highlighted Axis 2 as being significant with the highest correlation coefficients for $\mathrm{pH}(-0.5648)$ and fluoride (-0.4646). Likewise, $\mathrm{pH}$ and fluoride were the parameters that showed the greatest increases in relative weights comparing WQI-SANEAGO (2012) with WQI-VRP, $87.5 \%$ and $20.0 \%$, respectively. Thus, this analysis demonstrates that these parameters correspond to the critical variables of the study region and support the use of WQIVRP as an efficient tool to assess the quality of drinking water in Brazilian subtropical and temperate lotic systems.

\section{ACKNOWLEDGMENTS}

This work was carried out with the support of the Coordination for the Improvement of Higher Education Personnel - Brazil (CAPES) - Financing Code 001, with a doctoral scholarship granted to the first author.

\section{REFERENCES}

\section{APHA, AWWA, WEF. Standard Methods for the Examination of Water and Wastewater. 21th ed. Washington, DC, 2005.}


ARAVINTHASAMY, P.; KARUNANIDHI, D.; SUBRAMANI, T.; ROY, P. D. Demarcation of groundwater quality domains using GIS for best agricultural practices in the droughtprone Shanmuganadhi River basin of South India. Environmental Science and Pollution Research, v. 28, p. 1-13, 2021. https://doi.org/10.1007/s11356-020-08518-5

BAWOKE, G. T.; ANTENEH, Z. L. Spatial assessment and appraisal of groundwater suitability for drinking consumption in Andasa watershed using water quality index (WQI) and GIS techniques: Blue Nile Basin, Northwestern Ethiopia. Cogent $\begin{array}{lllllll}\text { Engineering, } & \text { v. } & 7, & \text { n. } & 1, & \text { p. } & 1748950,\end{array}$ https://doi.org/10.1080/23311916.2020.1748950

BAUMANN, L.; KLAMT. R. A.; SANTOS. R. B.; KIRST. A.; HELFER. G. A., LOBO, E. A.; COSTA, A. B. Aplicação do software Defluoridation no dimensionamento do sistema de desfluoretação de águas subterrâneas utilizando carvão ativado de osso granulado. Águas Subterrâneas, v. 32, n. 1, p. 61-69, 2018. https://doi.org/10.14295/ras.v32i1.29089

BRASIL. Ministério da Saúde. Portaria de consolidação no 5 , de 28 de setembro de 2017. Consolidação das normas sobre as ações e os serviços de saúde do Sistema Único de Saúde. Diário Oficial [da] União: seção 1, Brasília, DF, 28 set. 2017.

BRASIL. Ministério da Saúde. Portaria GM/MS Nº 518, de 25 de março de 2004. Estabelece os procedimentos e responsabilidades relativos ao controle e vigilância da qualidade da água para consumo humano e seu padrão de potabilidade, e dá outras providências. Brasília, DF: Editora MS, 2005.

BROWN, R. M.; MCCLELLAND, N. I.; DEININGER, R. A.; TOZER, R. G. A water quality index - do we dare? Water Sewage Works, v. 117, n. 10, p. 339-343, 1970.

CETESB. IAP - Índice de Qualidade das Águas Brutas para Fins de Abastecimento Público. São Paulo, 2002.

CONAMA (Brasil). Resolução n $^{\circ} 357$ de 17 de março de 2005. Dispõe sobre a classificação dos corpos de água e diretrizes ambientais para o seu enquadramento, bem como estabelece as condições e padrões de lançamento de efluentes, e dá outras providências. Diário Oficial [da] União: seção 1, Brasília, DF, n. 053, p. 58-63, 18 mar. 2005.

COSTA, A. B.; RODRIGUES, G. S.; BAUMANN, L.; SANTOS, R. B.; KLAMT, R. A.; CARVALHO, F. S. et al. Desfluoretação de águas subterrâneas por adsorção e precipitação por contato em carvão ativado de osso. Caderno de Pesquisa v. 30, n. Especial. 2018.

DURAISAMY, S.; GOVINDHASWAMY, V.; DURAISAMY, K.; KRISHINARAJ, S.; BALASUBRAMANIAN, A.; THIRUMALAISAMY, S. Hydrogeochemical characterization and evaluation of groundwater quality in Kangayam taluk, Tirupur district, Tamil Nadu, India, using GIS techniques. Environmental Geochemistry and Health, v. 41, n. 2, p. 851-873, 2019. https://doi.org/10.1007/s10653-018-0183-z

EDZWALD, J. K. Water Quality \& Treatment: A Handbook on Drinking Water. New York: McGraw Hill, 2010. 1696 p.

FACINCANI, V. R.; NARIYOSHI, M. A.; MENDES, W. W. S.; YOSHIMOTO, P.M. Metodologia para caracterização da qualidade da água distribuída na região metropolitana de São Paulo - RMSP. Revista brasileira de pesquisa e desenvolvimento, v. 3, n. 2, p. 113-120, 2001. 
FERNANDES, N. C.; SCALIZE, O. S. Comparação entre dois métodos para determinação da qualidade da água tratada. Ciência \& Engenharia, v. 24, n. 2, p. 85-93, 2015. http://dx.doi.org/10.14393/19834071.2015.30122

FUNDAÇÃO DE ECONOMIA E ESTATÍSTICA SIEGFRIED EMANUEL HEUSER. Município: Porto Alegre. COREDE Vale do Rio Pardo. 2019. Available at: https://arquivofee.rs.gov.br/perfilsocioeconomico/coredes/detalhe/?corede=Vale+do+Ri o+Pardo. Access: July 2021.

GAIKWAD, S.; MESHRAM, D.; WAGH, V.; KANDEKAR, A.; KADAM, A. Geochemical mobility of ions in groundwater from the tropical western coast of Maharashtra, India: implication to groundwater quality. Environment, Development and Sustainability, v. 22, n. 3, p. 2591-2624, 2020. https://doi.org/10.1007/s10668-019-00312-9

GOTELli, N. J.; ELLISON, A. M. A Primer of Ecological Statistics. 2. ed. Oxford: Sinauer Associates; Oxford University Press, 2013.

HAMMER, O.; HARPER, D. A. T.; RYAN, P. D. PAST: Paleontological Statistics Software Package for Education and Data Analysis. Palaeontologia Electronica, v. 4, n. 1, 9p, 2001.

JACKSON, D. A. Stopping rules in principal components analysis: a comparison of heuristical and statistical approaches. Ecology, v. 74, p. 2204-2214, 1993. https://doi.org/10.2307/1939574

KADAM, A.; WAGH, V.; PATIL, S. BHAVANA, U.; RABINDRANATH, S.; JAMES, J.; Seasonal variation in groundwater quality and beneficial use for drinking, irrigation, and industrial purposes from Deccan Basaltic Region, Western India. Environmental Science and Pollution Research, v. 28, p. 26082-26104, 2021. https://doi.org/10.1007/s11356-020-12115-x

KLAMT, R. A.; LOBO, E. A.; COSTA, A. B.; DELEVATI, D. M. Evaluation of water resource preservation areas in the Hydrographical Basin of Andreas Stream, RS, Brazil, using environmental monitoring programs. Revista Ambiente \& Água, v. 14, n. 2, p. 1-12, 2019. https://doi.org/10.4136/ambi-agua.2307

MARQUES, M. N.; DAUDE, L. F.; SOUZA, R. M. G. L.; COTRIM, M. E. B.; PIRES, M. A. F. Avaliação de um índice dinâmico de qualidade de água para abastecimento: um estudo de caso. Exacta, v. 5, n. 1, p. 47-55, 2007. https://doi.org/10.5585/exacta.v5i1.1029

MORETTO, D. L.; PANTA, E.; COSTA, A. B.; LOBO, E. A. Calibration of Water Quality Index (WQI) based on Resolution $n^{\circ} 357 / 2005$ of the Environment National Council (CONAMA) Brazil. Acta Limnologica Brasiliensia, v. 24, n. 1, p. 29-42, 2012. https://doi.org/10.1590/S2179-975X2012005000024

NASCIMENTO, R. S.; CURI, R. C.; CURI, W. F.; OLIVEIRA, R.; SANTANA, C. F. D.; MEIRA, C. M. B. S. Simulação de alterações numa ETA convencional de porte médio para a produção de água segura. Revista Brasileira de Recursos Hídricos, v. 21, n. 2, p. 439-450, 2016. https://doi.org/10.21168/rbrh.v21n2.p439-450

PAPPIS, C.; LIBRELOTTO, M; BAUMANN, L.; BERTUZZO, R.; SANTOS, R. B. S; SANTOS, R. O.; LOBO, E. A.; COSTA, A. B. Identificação de adulterações no carvão ativado de osso utilizado na desfluoretação de águas subterrâneas por NIRS-PLS-DA. Revista Águas Subterrâneas, v. 34, n. 3, p. 358-366, 2020. https://doi.org/10.14295/ras.v34i3.29944 
PIERIN, C. E.; KUlCHESKI, E.; GIONGO, E. M. S.; CHIARELlO, C. I.; SILVA, D. A. ACQAD - Avaliação de conformidade da qualidade da água distribuída nos 616 sistemas operados pela SANEPAR no estado do Paraná. SANARE, v. 23, n. 23, p. 4-16, 2005.

RICKWOOD, C. J.; CARR, G. M. Development and sensitivity analysis of a global drinking water quality index. Environmental Monitoring and Assessment, v. 156, n. 1-4, p. 7390, 2009. https://doi.org/10.1007/s10661-008-0464-6

SAFFRAN, K.; CASH, K.; HALLARD, K.; WRIGHT, R. Canadian Water Quality Guidelines for the Protection of Aquatic Life CCME WATER QUALITY INDEX 1.0 User's Manual. Canadian Water Quality Guidelines for the Protection of Aquatic Life: CCME Water Quality Index 1.0 users manual. Hull, QC: CCME, 2001.

SANEAGO. Índice de qualidade da água tratada - WQI. Goiânia, 2012.

SILVA, R. A. S.; MAYNARD, I. N. F.; BARBOSA, A. Q.; TOLLE, E. C.; CAVALCANTE, E. B.; MARQUES, M. N. Aplicação de um Índice de qualidade de água para o sistema de abastecimento público. Scientia Plena, v. 13, n. 10, p. 1-7. 2017. https://doi.org/10.14808/sci.plena.2017.109917

SUBBA, R. A. O. N.; DEEPALIM; DINAKAR, A.; CHANDANA, I.; SUNITHA, B.; RAVINDRA, B.; BALAJI, T. Geochemical characteristics and controlling factors of chemical composition of groundwater in a part of Guntur district, Andhra Pradesh, India. Environmental Earth Science, v. 76, n. 747, 2017. https://doi.org/10.1007/s12665-0177093-8

TER BRAAK, C. J. F.; PRENTICE, I. C. A theory of gradient analysis. Advances of Ecological Research, v. 18, p. 271-317, 1988. https://doi.org/10.1016/S00652504(08)60183-X

USEPA. Guidelines for Carcinogen Risk Assessment. EPA/630/P-03/001F. Washington, 2005.

VARADE, A. M.; YENKIE, R. O.; SHENDE, R. R.; GOLEKAR, R. B.; WAGH, V. M.; KHANDARE, H. W. Assessment of water quality for the groundwater resources of urbanized part of the Nagpur District, Maharashtra (India). American Journal of Water Resource, v. 6, n. 3, p. 89-11, 2018. https://dx.doi.org/10.12691/ajwr-6-3-1

WAGH, V.; MUKATE, S.; MULEY, A.; KADAM, A.; PANASKAR, D.; VARADE, A. Study of groundwater contamination and drinking suitability in basaltic terrain of Maharashtra, India through PIG and multivariate statistical techniques. Journal of Water Supply: Research and Technology-Aqua, v. 69, n. 4, p. 398-414, 2020. https://doi.org/10.2166/aqua.2020.108

WHO. Guidelines for drinking - water quality. 4th ed. Geneva, 2011. 564p.

WIESEL, P.; DRESCH, E.; SANTANA, E.; LOBO, E.; Avaliação da qualidade da água na Bacia Hidrográfica do Arroio Preto, Santa Cruz do Sul, RS, Brasil. Caderno de Pesquisa, v. 30, 2018. https://dx.doi/org/10.17058/cp.v30i1.12195 